\title{
Crisphead lettuce under influence of soil conditioner, organic fertilizers and liming
}

\author{
Edilene Carvalho Santos Marchi', Giuliano Marchi2*, \\ Carlos Alberto Silva ${ }^{3}$, Marco Antônio Rezende Alvarenga ${ }^{3}$ \\ 'Federal Institute of Education, Science and Technology of Brasilia, Planaltina, DF, Brazi \\ ${ }^{2}$ Brazilian Agricultural Research Corporation, Planaltina, DF, Brazil \\ ${ }^{3}$ Federal University of Lavras, Lavras, MG, Brazil \\ *Correspondente author, e-mail: giuliano.marchi@embrapa.br
}

\begin{abstract}
Lettuce is considered the main leafy vegetable crop in Brazil. High amounts of mineral and organic fertilizers are applied to soils during lettuce growth. There is a need of data concerning the effect of organic fertilizers and liming, including soil conditioners. Few studies were carried out verifying effects of soil conditioners, organic fertilizers and liming on lettuce production. The aim of this work was to test a soil conditioner composed of humic material, organic fertilizers and liming on "iceberg" lettuce production. The experiment was conducted at Federal University of Lavras, Minas Gerais State, Brazil, from March to July, in greenhouse conditions. The experimental design was completely randomized in a factorial scheme $5 \times 3 \times 2$. Five doses of soil conditioner $\left(0,20,40,100,200 \mathrm{~L} \mathrm{ha}^{-1}\right)$, 3 types of fertilizers (organic compost, chicken manure and mineral), with or without liming were studied. Fresh and dried biomass, commercial fresh and dried biomass, plants height, circumference of lettuce head, number of leaves, and dried root weight yield were evaluated. Chicken manure rendered the higher lettuce shoot commercial fresh weight and circumference than the other evaluated fertilizers. In general the soil conditioner did not influence lettuce production. The use of liming was very important on lettuce production when mineral fertilizers were used.
\end{abstract}

Keywords: Lactuca sativa L., chicken manure, organic compost, lime, humic substances

\section{Alface americana sob influência da adubação orgânica, calagem e condicionador de solo}

\section{Resumo}

Alface é considerada a principal hortaliça folhosa no Brasil.Grandes quantidades de fertilizantes minerais e orgânicos são aplicados aos solos durante o seu cultivo. Existe uma necessidade de se ter maior informação sobre os efeitos de fertilizantes orgânicos e condicionadores de solo. Poucos estudos foram conduzidos no sentido de se verificar os efeitos da calagem, condicionadores de solo e de fertilizantes orgânicos aplicados conjuntamente na produção de alface. O objetivo deste trabalho foi testar fertilizantes orgânicos, calagem e um condicionador de solo composto de material húmico na produção de alface cv. iceberg. O experimento foi realizado na Universidade Federal de Lavras, Minas Gerais, de março a julho, em casa de vegetação. O delineamento experimental utilizado foi completamente ao acaso em um esquema fatorial $5 \times 3 \times 2$. Foram estudadas cinco doses de condicionador de solo $\left(0,20,40,100,200 \mathrm{~L} \mathrm{ha}^{-1}\right.$ ), em três tipos de adubação(composto orgânico, esterco de galinha e mineral) com e sem calagem. Foram avaliadas a biomassa fresca e seca, a biomassa comercial fresca e seca, altura de plantas, circunferência da cabeça de alface, número de folhas e peso de raízes frescas e secas. O esterco de galinha proporcionou o maior rendimento na parte aérea comercial fresca e na circunferência que os outros fertilizantes estudados. Em geral, o condicionador de solo não influenciou a produção de alface. O uso da calagem foi muito importante na produção de alface quando fertilizantes minerais foram utilizados.

Palavras-chave: Lactuca sativa L., esterco de aves, composto orgânico, calcário, substâncias húmicas 


\section{Introduction}

Originated from the Mediterranean Region, the lettuce (Lactuca sativa) is the main leaf vegetal in the horticulture in world (Sala \& Costa, 2012). Lettuce is one of the most important vegetables sold in Brazilian market, and also has a great socioeconomic impact in most countries where it is produced. Lettuce presents a rapid production cycle, exuberating leaves, and demands rich soils for success in its production. Use of organic fertilizers benefits physical, chemical, and biological characteristics of soils(Wander, 2004).

Organic fertilizers, such as organic compost or chicken manure, when applied to soils, release plant nutrients slowly, which are absorbed from soil solution along with plant requirement. The residual effect of organic fertilizers on nutrients release depends on its source and decomposition degree/Gliessman, 2001). Animal or vegetal residues applied to soils enhance its chemical characteristics (Naramabuye et al., 2008). Chicken as well as cattle manure complex toxic $\mathrm{Al}$, enhances soil $\mathrm{pH}$, and phosphorus, calcium, and magnesium content (Materechera \& Mkhabela, 2002; Yagi et al., 2003; Steiner et al., 2007).For lettuce production some studies with organic fertilizers, such as organic compost (Yuri et al., 2004), and vermicompost (Mantovani et al., 2003), manure (Bosshard et al.,2009; Oberson et al., 2010; Kiba et al., 2012) were realized.

Recently, a number of commercial products, such as soil conditioners produced from humic substances, such as humic and fulvic acids, for use in agricultural soils, have been sold worldwide. These products are told to amend soils, increasing soil carbon content rather than provide nutrients, unless there are plant nutrients mixed in the product beforehand. The growing interest on these substances is due to its associated benefits. Humic acids added to soils increase cation exchange capacity, stimulate microbial activity, and increase soil capacity to complex and solubilize ions (Gudugi, 2013). These acids, in agricultural systems, are the main components of soil organic matter. Humic acids also improve important soil functions, such as $\mathrm{pH}$ buffering, water retention, plant growth stimulation, detoxification of toxic pollutants, and behave as reducing agents (Rodrigues et al., 2014). Humic acids may be extracted from low rank coal, such as leonardite and applied in soils for agricultural uses (Fernández-Escobar et al., 2008).

The aim of this work was to evaluate the effect of doses of a soil conditioner extracted from leonardite, and three kinds of fertilizer (organic compost, chicken manure and mineral), with or without liming on lettuce (cv. iceberg) production.

\section{Material and Methods}

The present experiment was carried out in a greenhouse, in Lavras, Minas Gerais State. Samples $(0-20 \mathrm{~cm})$ of a soil classified as Typic Kandiudox were collected for chemical analysis (Table 1). Experimental design was completely randomized in a factorial scheme $5 \times 3 \times 2$. Five doses of soil conditioner $(0,20,40,100,200 \mathrm{~L} \mathrm{ha}$ 1), 3 types of fertilizers (organic compost, chicken manure and mineral), with or without liming were studied, with five replications, totalizing 150 experimental plots.

Liming was performed to increase basis saturation to $60 \%$. In $70 \mathrm{~kg}$ of soil, it was applied $211.4 \mathrm{~g}$ ofdolomitic lime, equivalent to $6.04 \mathrm{t}$ ha-1 of lime. Chicken manure (CKM), organic compost (OCP) produced from cattle manure and cultural remains, or mineral fertilizers were added to the soil. To these mixtures, five doses of a soil conditioner ( $\mathrm{SCN}$ ) extracted from leonardite, classified as "B" (MAPA, 2006) were applied (Table 2). The soil $\left(2.75 \mathrm{~kg} \mathrm{pot}^{-1}\right)$ was incubated with the treatments for 10 days before lettuce planting.

The amount of organic fertilizers $(24.19 \mathrm{~g}$ of CKM kg-1 or $54.83 \mathrm{~g}$ of OCP kg-1) was mixed to the soil to provide the recommended nitrogen doses (300 mg N kg-1; Novais et al., 1991) also considering $50 \%$ availability during the cropping season (CFSEMG, 1999). These amounts of organic fertilizers were equal to $2.27 \mathrm{mg} \mathrm{C}$-CKM

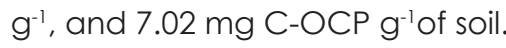

Mineral fertilization was performed by mixing phosphorus (simple superphosphate, 300 mg $\mathrm{P} \mathrm{kg}^{-1}$ ) to the soil. Nitrogen ( $\mathrm{N}$-urea, $300 \mathrm{mg}$ $\mathrm{N} \mathrm{kg}^{-1}$ ), and potassium (potassium phosphate, $300 \mathrm{mg} \mathrm{K} \mathrm{kg}$ ) were supplied to soil (split in 4 
Table 1. Soil physical and chemical characteristics.

\begin{tabular}{|c|c|}
\hline Characteristics $^{\S}$ & Values \\
\hline $\mathrm{pH}$ in water & 5.0 \\
\hline$P\left(\mathrm{mg} \mathrm{dm}^{-3}\right)$ & 0.6 \\
\hline remaining phosphorus (mg $\mathrm{L}^{-1}$ ) & 4.7 \\
\hline $\mathrm{K}\left(\mathrm{mg} \mathrm{dm^{-3 } )}\right.$ & 33.0 \\
\hline $\mathrm{Ca}\left(\mathrm{cmol}_{\mathrm{c}} \mathrm{dm}^{-3}\right)$ & 0.4 \\
\hline $\mathrm{Mg}\left(\mathrm{cmol}_{\mathrm{c}} \mathrm{dm}^{-3}\right)$ & 0.2 \\
\hline $\mathrm{Al}\left(\mathrm{cmol}_{\mathrm{c}} \mathrm{dm}^{-3}\right)$ & 1.3 \\
\hline $\mathrm{H}+\mathrm{Al}\left(\mathrm{cmol}_{\mathrm{c}} \mathrm{dm}^{-3}\right)$ & 9.8 \\
\hline $\mathrm{SB}^{\#}\left(\mathrm{cmol}_{\mathrm{c}} \mathrm{dm}^{-3}\right)$ & 0.7 \\
\hline$t^{*}\left(\mathrm{cmol}_{\mathrm{c}} \mathrm{dm}^{-3}\right)$ & 2.0 \\
\hline $\mathrm{T}\left(\mathrm{cmol}_{\mathrm{c}}^{\mathrm{c}} \mathrm{dm}^{-3}\right)$ & 10.5 \\
\hline$\vee^{\Pi}(\%)$ & 7 \\
\hline$m^{\nabla}(\%)$ & 66 \\
\hline $\operatorname{Corg}^{\Delta}\left(\mathrm{mg} \mathrm{g}^{-1}\right)$ & 39.5 \\
\hline $\mathrm{Zn}\left(\mathrm{mg} \mathrm{dm}^{-3}\right)$ & 0.6 \\
\hline $\mathrm{Fe}\left(\mathrm{mg} \mathrm{dm}^{-3}\right)$ & 227 \\
\hline$M n\left(\mathrm{mg} \mathrm{dm}^{-3}\right)$ & 7.6 \\
\hline $\mathrm{Cu}\left(\mathrm{mg} \mathrm{dm} \mathrm{m}^{-3}\right)$ & 1.1 \\
\hline$B\left(\mathrm{mg} \mathrm{dm}^{-3}\right)$ & 0.5 \\
\hline S-sulphate $\left(\mathrm{mg} \mathrm{dm}^{-3}\right)$ & 8.0 \\
\hline Sand $\left(\mathrm{g} \mathrm{kg}^{-1}\right)$ & 190 \\
\hline Silt $\left(\mathrm{g} \mathrm{kg}^{-1}\right)$ & 120 \\
\hline Clay $\left(\mathrm{g} \mathrm{kg}^{-1}\right)$ & 690 \\
\hline
\end{tabular}

Table 2. Organic fertilizers and soil conditioner characteristics.

\begin{tabular}{|c|c|c|c|}
\hline Characteristics $\S$ & CKM* $^{*}$ & OCP & $\mathrm{SCN}$ \\
\hline $\mathrm{pH}$ in water & 8.90 & 7.60 & 14.30 \\
\hline $\mathrm{N}$-total $\left(\mathrm{g} \mathrm{kg}^{-1}\right)$ & 25.80 & 12.00 & 4.00 \\
\hline$P\left(g ~ k g^{-1}\right)$ & 25.75 & 4.24 & 34.44 \\
\hline$K\left(g \mathrm{~kg}^{-1}\right)$ & 22.28 & 6.81 & 37.12 \\
\hline $\mathrm{Na}\left(\mathrm{g} \mathrm{kg}^{-1}\right)$ & - & - & 115.00 \\
\hline $\mathrm{Ca}\left(\mathrm{g} \mathrm{kg}^{-1}\right)$ & 102.50 & 25.48 & 1.66 \\
\hline$M g\left(g \mathrm{~kg}^{-1}\right)$ & 6.12 & 3.02 & 0.26 \\
\hline S-sulphate $\left(\mathrm{g} \mathrm{kg}^{-1}\right)$ & 5.23 & 5.23 & 7.50 \\
\hline$B\left(\mathrm{mg} \mathrm{kg}^{-1}\right)$ & 35.00 & 106.00 & - \\
\hline $\mathrm{Cu}\left(\mathrm{mg} \mathrm{kg}^{-1}\right)$ & 68.00 & 43.00 & 0.00 \\
\hline $\mathrm{Fe}\left(\mathrm{g} \mathrm{kg}^{-1}\right)$ & 2.18 & 48.38 & 102.10 \\
\hline $\mathrm{Mn}\left(\mathrm{mg} \mathrm{kg}^{-1}\right)$ & 552.00 & 468.00 & 7.10 \\
\hline $\mathrm{Zn}\left(\mathrm{mg} \mathrm{kg}^{-1}\right)$ & 503.00 & 473.00 & 16.20 \\
\hline Humidity (dag kg-1) & 16.58 & 6.16 & - \\
\hline $\mathrm{OC}\left(\mathrm{mg} \mathrm{g}^{-1}\right)$ & 94.00 & 128.00 & 59.00 \\
\hline Density $\left(\mathrm{g} \mathrm{cm}^{-3}\right)$ & - & - & 1.23 \\
\hline
\end{tabular}

aplications: 7, 15, 21, and 28 days after lettuce planting). Micronutrients $\left(0.5 \mathrm{mg} \mathrm{B} \mathrm{kg}{ }^{-1}, 5.0 \mathrm{mg}\right.$ $\mathrm{Zn} \mathrm{kg}{ }^{-1}, 1.5 \mathrm{mg} \mathrm{Cu} \mathrm{kg}{ }^{-1}, 0.15 \mathrm{mg} \mathrm{Mo} \mathrm{kg}^{-1}$ ) were applied only once ( 10 days after planting lettuce seedlings).

Soil conditioner composed of $229 \mathrm{~g}$ humic extract total $\mathrm{L}^{-1}$, in which 113 ghumic acids $\mathrm{L}^{-1}$, and $116 \mathrm{~g}$ fulvic acids $\mathrm{L}^{-1}$, in liquid form, was applied to soil (7 days after planting lettuce seedlings, at a rate of $0,20,40,100$ e $200 \mathrm{~L} \mathrm{ha}^{-1}$, based on plant population - 0, 0.3986, 0.7972, 1.993, and $3.986 \mathrm{~g}$ pot $^{-1}$ were applied, respectively). Total amount of C provided from SCN to pots was 0.9, 1.8, 4.5 e 9.1 $\mu \mathrm{g} \mathrm{C} \mathrm{g}^{-1}$ of soil, respectively.

Lettuce seedlings (iceberg, cv. Raider) were planted 35 days after germination when they had four leaves. Plants were harvested 57 days after planting. After harvesting, 3 
replications of soil samples were collected, with a total of 450 samples. Soil samples were air dried, and prepared to further analysis.

After harvesting lettuce height, circumference, total number of leaves, fresh and dried shoot weight, fresh and dried shoot commercial (lettuce without external leaves) weight, and dried root weight were measured.

Analysis of variance was performed to test lettuce production as a function of tested factors (soil conditioner, fertilizers and liming). Scott Knott test, 5\% probability was performed. Regression analysis was performed on SCN data.

\section{Results and Discussion}

There was no triple statistical interaction (SCN, fertilizers and liming) with lettuce evaluated characteristics, except with lettuce dried shoot weight. This latter characteristic interacted significantly with liming, fertilizers, and doses of SCN (Table 3). Lettuce dried shoot weight was higher when produced with CKM than with OCP or mineral fertilizers within all SCN doses. The higher amount of lettuce dried shoot weight produced withuse of CKM than that verified with mineral fertilizer is due, mainly, to the increase of soil $\mathrm{pH}$ and $\mathrm{Ca}$ concentrationwhen this fertilizer was applied (Table 4). When lime was applied, CKM and mineral fertilization produced the same lettuce dried shoot weight. In spite of the amount of OCP applied be practically the double of that of CKM,OCP was poorer in $\mathrm{P}, \mathrm{K}$, and $\mathrm{Ca}$, and richer in $\mathrm{B}$ (Table 2). In addition, CKM has a smaller ratio $\mathrm{C}: \mathrm{N}$ than $\mathrm{OCP}$, decomposing faster, thus lettuce dried shoot weight, produced with $\mathrm{OCP}$, was lower than with CKM. The amount of $\mathrm{B}$ applied with OCP was very high (11.62 $\left.\mathrm{kg} \mathrm{ha}^{-1}\right)$. Boron average concentration in lettuce leaves produced with OCP was 127 and $146 \mathrm{mg} \mathrm{kg}^{-1}$ with and without liming, respectively. Boron toxicity reduced the growth of lettuce plants damaging membranes and the antioxidant defense system (Malavolta, 2006). Symptoms of B toxicity in lettuce produced with OCP appeared an the edges of leaves, and progressed to a browning and drying of margins and tips for most of the fully expanded leaves.Similar symptoms were found by Choi et al. (2006) with $515 \mathrm{mg} \mathrm{B} \mathrm{kg}^{-1}$ of lettuce dried leaves and Pereira et al., (2005).Adequate values for B in lettuce leaves are $30-60 \mathrm{mg} \mathrm{kg}$ '(Van Raij et al., 1997).

The addition of organic amendments increase soil $\mathrm{pH}$ and reduce exchangeable $\mathrm{Al}$ regardless of whether lime was applied or not (Mokolobate \& Haynes, 2003; Yagi et al., 2003). Lettuce dried shoot weight produced with CKM was the same with or without liming (Table 5). Soil $\mathrm{pH}$ increase was higher with CKM than with $\mathrm{OCP}$, due to CKM higher $\mathrm{pH}$ (Table 2). However, liming decreased the dried shoot weight produced with OCP (Table 5). There was no evidence found in nutrient concentrations in lettuce leaves which could explain this decrease due to liming.

Increases in SCN, with CKM as fertilizer and lime, lead to a linear increase in lettuce dried shoot weight $\left[y=0.0167 x+26.369\left(R^{2}=0.45\right)\right]$. With OCP, fertilizer and lime increases in SCN caused a linear decrease in lettuce dried shoot weight $\left[y=19,026-0,0219 x\left(R^{2}=0.71\right)\right]$. Decreases in lettuce dried shoot weight produced with OCP with increases in SCN may be due to the enhanced uptake of B caused by humic acids

Table 3. Lettuce dried shoot weight as a function of fertilizers within liming versus doses of soil conditioner (SCN).

\begin{tabular}{|c|c|c|c|c|}
\hline \multirow{3}{*}{ Liming } & \multirow{3}{*}{ Dose of SCN $\left(\mathrm{L} \mathrm{ha}^{-1}\right)$} & \multicolumn{3}{|c|}{ Fertilization } \\
\hline & & $\mathrm{CKM}^{\S}$ & OCP & Mineral \\
\hline & & \multicolumn{3}{|c|}{ Dried shoot weight $(g)^{*}$} \\
\hline \multirow[t]{5}{*}{ Without } & 0 & $28.84 a$ & $24.19 b$ & $19.59 \mathrm{C}$ \\
\hline & 20 & $30.11 \mathrm{a}$ & $22.13 b$ & $19.26 \mathrm{~b}$ \\
\hline & 40 & $28.91 \mathrm{a}$ & $21.92 \mathrm{~b}$ & $21.28 \mathrm{~b}$ \\
\hline & 100 & $25.64 a$ & $21.57 \mathrm{a}$ & $23.96 a$ \\
\hline & 200 & $30.04 a$ & $20.76 \mathrm{~b}$ & $20.76 \mathrm{~b}$ \\
\hline \multirow[t]{5}{*}{ With } & 0 & $25.93 a$ & $20.00 \mathrm{~b}$ & $27.05 a$ \\
\hline & 20 & $25.09 a$ & $18.80 \mathrm{~b}$ & $25.41 \mathrm{a}$ \\
\hline & 40 & $29.46 a$ & $16.23 \mathrm{~b}$ & $26.22 a$ \\
\hline & 100 & $27.95 a$ & $17.56 \mathrm{C}$ & $23.76 \mathrm{~b}$ \\
\hline & 200 & $29.44 \mathrm{a}$ & $14.64 \mathrm{~b}$ & $27.42 a$ \\
\hline
\end{tabular}


Table 4. Soil pH as a function of fertilizers within liming versus doses of soil conditioner (SCN).

\begin{tabular}{|c|c|c|c|c|}
\hline \multirow{3}{*}{ Liming } & \multirow{3}{*}{ Dose of SCN } & \multicolumn{3}{|c|}{ Fertilization } \\
\hline & & $\mathrm{CKM}^{\S}$ & $\mathrm{OCP}$ & Mineral \\
\hline & & \multicolumn{3}{|c|}{$\mathrm{pH}$} \\
\hline \multirow[t]{5}{*}{ Without } & 0 & 5.65 & 5.50 & 4.75 \\
\hline & 20 & 5.90 & 5.60 & 4.70 \\
\hline & 40 & 5.90 & 5.45 & 4.65 \\
\hline & 100 & 5.95 & 5.55 & 4.55 \\
\hline & 200 & 5.85 & 5.50 & 4.55 \\
\hline \multirow[t]{5}{*}{ With } & 0 & 6.40 & 5.80 & 5.40 \\
\hline & 20 & 6.35 & 5.95 & 5.40 \\
\hline & 40 & 6.40 & 6.15 & 5.35 \\
\hline & $n$ & 6.40 & 5.95 & 5.55 \\
\hline & 200 & 6.40 & 6.15 & 5.85 \\
\hline
\end{tabular}

Table 5. Lettuce dried shoot weight as a function of liming within fertilizers versus doses of soil conditioner (SCN).

\begin{tabular}{|c|c|c|c|}
\hline \multirow{2}{*}{ Fertilization } & \multicolumn{3}{|c|}{ Dried shoot weight $(g)^{*}$} \\
\hline & Doses of SCN & Without liming & With liming \\
\hline \multirow[t]{5}{*}{$C K M^{\S}$} & 0 & $28.84 a$ & $25.93 a$ \\
\hline & 20 & $30.11 \mathrm{a}$ & $25.09 \mathrm{~b}$ \\
\hline & 40 & $28.91 \mathrm{a}$ & $29.46 a$ \\
\hline & 100 & $25.64 a$ & $27.95 a$ \\
\hline & 200 & $30.04 a$ & $29.44 a$ \\
\hline \multirow[t]{5}{*}{ OCP } & 0 & $24.19 a$ & $20.00 \mathrm{~b}$ \\
\hline & 20 & $22.13 a$ & $18.80 \mathrm{a}$ \\
\hline & 40 & $21.92 \mathrm{a}$ & $16.23 \mathrm{~b}$ \\
\hline & 100 & $21.57 \mathrm{a}$ & $17.56 \mathrm{~b}$ \\
\hline & 200 & $21.29 a$ & $14.64 \mathrm{~b}$ \\
\hline \multirow[t]{5}{*}{ Mineral } & 0 & $19.59 \mathrm{~b}$ & $27.05 a$ \\
\hline & 20 & $19.26 \mathrm{~b}$ & $25.41 \mathrm{a}$ \\
\hline & 40 & $21.28 b$ & $26.22 \mathrm{a}$ \\
\hline & 100 & $23.96 a$ & $23.76 a$ \\
\hline & 200 & $20.76 \mathrm{~b}$ & $27.42 a$ \\
\hline
\end{tabular}

added to the soil with SCN. Angin et al. (2008) verified that increases in humic acids enhanced the phytoexctraction of $\mathrm{B}$ by Vetiveria zizanioides (L.) (Nash).

Lettuce height, shoot fresh weight, commercial shoot fresh and dried weight, and dried root weight had significant interaction with liming and fertilizers (Table 6). However, lettuce number of leaves and circumference were affected only by fertilizers or liming (Table 7).

The use of liming increased lettuce height, shoot fresh weight, shoot commercial fresh and dried weight, and root dried weight when mineral fertilizers were applied. Lettuce height was highest when produced with mineral fertilizers. However, root dried weight was the lowest with mineral fertilizers. Even though lettuce root weight produced with OCP was higher than with mineral fertilizers, lettuce production with mineral fertilizers was higher in most of its characteristics. Lettuce root produced with OCP was higher than with mineral due to OCP properties, such as soil conditioning, reduced exchangeable acidity (Haynes \& Mokolobate, 2001), and higher water holding capacity (Gil et al., 2008). Lettuce shoot production with OCP was smaller than with mineral fertilizers because $P$ and $\mathrm{K}$ were present in lower proportions, and $\mathrm{B}$ was in high concentration in OCP. Liming also increased lettuce shoot fresh weight and shoot commercial fresh weight when produced with CKM, and decreased height and shoot commercial dried weight when produced with OCP.

With regard to the number of leaves and circumference, lettuce produced with CKM produced the highest values when compared with OCP and mineral Fertilizers. Liming decreased the number of leaves, but increased circumference in the other hand. 
Table 6. Height, shoot fresh weight, shoot commercial fresh and dried weight, and root dried weight as a function of fertilizers and liming.

\begin{tabular}{cccc}
\hline & \multicolumn{1}{c}{ CKM $^{\S}$} & OCP & Mineral \\
\cline { 2 - 4 } Liming & & Height $(\mathrm{cm})^{*}$ & \\
\hline Without & $20.98 \mathrm{~A} \mathrm{a}$ & $19.50 \mathrm{~B} \mathrm{a}$ & $19.76 \mathrm{~B} \mathrm{~b}$ \\
With & $20.66 \mathrm{~B} \mathrm{a}$ & $18.30 \mathrm{C} \mathrm{b}$ & $22.78 \mathrm{~A} \mathrm{a}$ \\
& & Shoot fresh weight $(\mathrm{g})$ & \\
Without & $498.03 \mathrm{~A} \mathrm{~b}$ & $285.83 \mathrm{~B} \mathrm{a}$ & $312.40 \mathrm{~B} \mathrm{~b}$ \\
With & $541.84 \mathrm{~A} \mathrm{a}$ & $268.64 \mathrm{C} \mathrm{a}$ & $442.73 \mathrm{~B} \mathrm{a}$ \\
& & Shoot commercial fresh weight (g) & \\
Without & $292.54 \mathrm{~A} \mathrm{~b}$ & $136.09 \mathrm{C} \mathrm{a}$ & $176.83 \mathrm{~B} \mathrm{~b}$ \\
With & 327.77 A a & $148.28 \mathrm{C} \mathrm{a}$ & $265.76 \mathrm{~B} \mathrm{a}$ \\
& & Shoot commercial dried weight (g) & \\
Without & $17.12 \mathrm{~A} \mathrm{a}$ & $10.54 \mathrm{C} \mathrm{a}$ & $12.17 \mathrm{~B} \mathrm{~b}$ \\
With & $16.40 \mathrm{~A} \mathrm{a}$ & $9.18 \mathrm{C} \mathrm{b}$ & $13.99 \mathrm{~B} \mathrm{a}$ \\
& & $12.92 \mathrm{~B} \mathrm{a}$ & $3.40 \mathrm{C} \mathrm{b}$ \\
Without & $15.15 \mathrm{~A} \mathrm{a}$ & $12.42 \mathrm{~B} \mathrm{a}$ & $8.37 \mathrm{C} \mathrm{a}$ \\
With & $14.97 \mathrm{~A} \mathrm{a}$ & Root dried weight (g) & \\
Lettuce characteristics in the same rows followed by same upper case letter, and the value in the same columns followed by same lower case letter were
\end{tabular}

not significantly different (Scott Knott, $\mathrm{p} \leq 5 \%$ ). ${ }^{.} \mathrm{CKM}=$ chicken manure; $\mathrm{OCP}=$ organic compost; Mineral = mineral fertilizers.

Table 7. Number of leaves and circumference as a function of fertilizers and liming.

\begin{tabular}{ccc}
\hline Fertilizer & Number of leaves & Circumference $(\mathrm{cm})$ \\
\hline $\mathrm{CKM}^{\S}$ & $27.74 \mathrm{a}$ & $41.78 \mathrm{a}$ \\
OCP & $24.18 \mathrm{~b}$ & $36.34 \mathrm{~b}$ \\
Mineral & $24.32 \mathrm{~b}$ & $36.12 \mathrm{~b}$ \\
Liming & & \\
\hline Without & $26.16 \mathrm{a}$ & $37.32 \mathrm{~b}$ \\
With & $24.66 \mathrm{~b}$ & $38.82 \mathrm{a}$ \\
\hline${ }^{2} \mathrm{CKM}=$ chicken manure; OCP $=$ organic compost; Mineral $=$ mineral fertilizers.
\end{tabular}

\section{Conclusions}

The soil conditioner did not change lettuce characteristics, except when produced with CKM or OCP in limed soil. The production with the former was increased, and with the latter decreased linearly.

As the most important lettuce characteristics for consumers are shoot commercial fresh weight and circumference, use of CKM and liming produced better results than the other evaluated methods.

When using only mineral fertilizers to lettuce production, liming was essential to increase all evaluated characteristics.

\section{References}

Angin, I., Turan, M., Ketterings, Q.M., Cakici, A. 2008. Humic acid addition enhances B and $\mathrm{Pb}$ phytoextraction by vetiver grass (Vetiveria zizanoides (L.) Nash). Water, Air and Soil Pollution 188: 335-343.

Bosshard, C., Sorensen, P., Frossard, E., Dubois, D. Mäder, P., Nanzer, S., Oberson, A., 2009. Nitrogen use efficiency of $15 \mathrm{~N}$-labelled sheep manure and mineral fertiliser applied to microplots in long-term organic and conventional cropping systems. Nutrient Cycling in Agroecosystems 83: 271-287.

Choi, E., Mcneill, A., Coventry, D., Stangoulis, J. 2006. Whole plant response of crop and weed species to high subsoil boron. Australian Journal of Agricultural Researchv 57: 761-770.

Van Raij, B., Cantarella, J.A., Quaggio, J.A., Furlani, A.M.C. 1997.Recomendações de adubação e calagem para o Estado de São Paulo. Campinas: Instituto Agronômico de Campinas, 285p.

Comissão de Fertilidade do Solo do Estado de Minas Gerais - CFSEMG. 1999. Recomendações para o uso de corretivos e fertilizantes em Minas Gerais, $5^{\circ}$ aproximação. Viçosa: UFV, 359 p.

Empresa Brasileira de Pesquisa Agropecuária - Embrapa. Centro Nacional de Pesquisas de Solos (Rio de Janeiro, R. J.). 1999. Manual de análises químicas de solos. Brasília: Embrapa Comunicação para transferência de tecnologia, $370 \mathrm{p.}$

Fernández-Escobar, R., Benlloch, M., Barranco, D., Dueñas, J.A., Gil, M.V., Calvo, L.F., Blanco, D., Sánchez, M.E. 2008. Assessing the agronomic and environmental effects of the application of cattle 
manure compost on soil by multiveriate methods. Bioresource Technology, Kidlington 99: 5763-5772.

Gliessman, S.R.2001. Agroecologia: processos ecológicos em agricultura sustentável.2.ed. Porto Alegre: UFRGS, 653p.

Gudugi I.A.S. 2013.Effects of cow dung and variety on the growth and yield of Okra (Abelmuschus esculentus L.), European Journal on Experimental Biology, 3(2): 495-498.

Haynes, R.J., Mokolobate, M.S. 2001 .Amelioration of Al toxicity and $\mathrm{P}$ deficiency in acid soils by additions of organic residues: a critical review of the phenomenon and the mechanisms involved. Nutrient Cycling in Agroecosystems 59:47-63.

Kiba, D. I., Zongoa, N. A., Lompo, F., Jansa J., Compaore, E., Sedogo, P.M., Frossard, E. 2012. The diversity of fertilization practices affects soil and crop quality in urban vegetable sites of Burkina Faso. European Journal of Agronomy 38:12-21.

Malavolta, E. 2006. Manual de nutrição mineral de plantas. São Paulo: Editora Agronômica Ceres. 638p.

Mantovani, J.R., Ferreira, M.E., Cruz, M.C.P., Chiba, M.K., Braz, L.T. 2003. Calagem e adubação com vermicomposto de lixo urbano na produção e nos teores de metais pesados em alface. Horticultura Brasileira 21 (3):494-500.

Materechera, S.A., Mkhabela, T.S. 2002. The effectiveness of lime, chicken manure and leaf litter ash in ameliorating acidity in a soil previously under black wattel (Acacia mearnsii) plantation. Bioresource Technologyv 85:9-16.

Ministério da Agricultura, Pecuária e Abastecimento - MAPA. 2006. Instrução Normativa n³5, de 4 de julho de 2006.

Mokolobate, M.S., Haynes, R.J. 2003. A glasshouse evaluation of the comparative effects of organic amendments, lime and phosphate on alleviation of Al toxicity and $\mathrm{P}$ deficiency in an Oxisol. Journal of Agricultural Science 140:409-417.

Naramabuye, F.X., Haynes, R.J., Modi, A.T. 2008. Cattle manure and grass residues as liming materials in a semi-substence farming system. Agriculture, Ecosystems and Environment 124:36141

Novais, R.F., Neves, J.E.L., Barros, N.F. 1991.Teores de nutrientes a serem adicionados ou atingidos em ensaios de vaso In: Oliveira, A.J.; Garrido, W.E.; ARAÚJO, J.D.; LourençO, S. (Eds.). Métodos de Pesquisa em Fertilidade do Solo. Brasilia: Embrapa/SEA, p.195-195.

Oberson, A., Tagmann, H.U., Langmeier, M., Dubois, D., Mäder, P., Frossard, E., 2010. Fresh and residual phosphorus uptake by ryegrass from soils with different fertilization histories. Plant Soil, 334: 391-407.

Pereira, C., Junqueira, A.M.R., Oliveira, S.A.2005. Balanço nutricional e incidência de queima de bordos em alface produzida em sistema hidropônico - NFT. Horticultura Brasileira 23(3): 810-814.

Rodrigues, E.T., Casali, V.W.D. 1999. Rendimento e concentração de nutrientes em alface, em função das adubações orgânica e mineral. Horticultura Brasileira 17: 125-128.

Rodrigues, F.O.S., Guimarães, V.F., Silva, M.B., Pinto Júnior, A.S., Klein, J., Costa, A.C.P.R. 2014. Características agronômicas do trigo em função de Azospirillum brasilense, ácidos húmicos e nitrogênio em casa de vegetação. Revista Brasileira de Engenharia Agrícola e Ambiental 18(1): 31-37.

Sala, F.C. \& Costa, C.da C. 2012. Retrospectiva e tendência da alfacicultura brasileira. Horticultura Brasileira 30: 187-194.

Steiner, C., Teixeira, W.G., Lehmann, J., Nehls, T., Macêdo, J.L.V., Blum, W.E.H., Zech, W. 2007. Long term effects of manure, charcoal and mineral fertilization on crop production and fertility on a highly weathered Central Amazonian upland soil. Plant and Soil 291:275-290.

Tuzel,Y., Engindeniz, S. 2006. Economic analysis of organic greenhouse lettuce production in Turkey. Scientia Agricola, Piracicaba 63(3): 285-290.

Wander, M. 2004. Soil organic matter fractions and their relevance to soil function. In: Magdoff, F.; Weil, R.R. (Eds.). Soil organic matter in sustainable agriculture. London, 67-102p.

Yagi, R., Ferreira, M.E., Cruz, M.C.P., Barbosa, J.C. 2003. Organic matter fractions and soil fertility under the influence of liming, vermicompost and cattle manure. Scientia Agricola 60:549-557.

Yuri,J.E., Resende, G.M., Rodrigues Júnior, J.C., Mota,J.H., Souza, R.J. 2004. Efeito de composto orgânico sobre a produção e características comerciais de alface americana. Horticultura Brasileira 22(1):127-130. 